\title{
Looking Within and Without: The Path to Tread By Muslims
}

\author{
Shamsul Khan*, Mahjabeen Ahmad
}

\begin{abstract}
There is no doubt that relation between the Muslim world and the West is often dominated by simmering distrust and antagonistic feelings although they may not always boil over. Tensions and recriminations abound and so do arguments and justifications. The need to find common grounds do not get translated into intentions or sincere efforts to move forward as the past casts a long shadow over the present. Typecasting a billion-plus fellow human beings or their faith as objects of dread or hatred as is being done by the West through fomenting Islamophobia needs to be prevented. Muslims must be able to reassert their true identity and earn their rightful place in a world dominated by Western power and influence. This may begin to happen if Muslims denounce and repudiate all the wrong that is being done in the name of their great religion, speak for themselves, develop religious and community leaders who are well equipped to impart the right knowledge and effectively address contemporary issues that confront Muslim societies and countries, and revive the spirit and unity of the ummah. Only then can they effectively fight not just the menace of Islamophobia, but also the injustices and discrimination in their own countries and those that are perpetrated by the West. The West must also turn their gaze inward and admit their role in creating this 'Great Divide'; they need to realize that their overbearing attitude toward Muslims and relentless depiction of the latter as their common folk devil will inevitably have undesirable, serious, and long-term consequences.
\end{abstract}

Key Words: $\quad$ Islamophobia, Islam, Muslims, Terrorism, Freedom of expression, Secularism, Jihad, Integration, Identity, Ummah

\footnotetext{
${ }^{*}$ Shamsul Khan, $\mathrm{PhD}$, is the Director of Postgraduate Programmes in International Studies at the School of Communication, International Studies and Languages, University of South Australia, Adelaide, Australia. The key areas of his teaching and research interests include intercultural understanding, Islam and the contemporary world, strategic and nonstrategic security, and moral economy and sustainable development. Email: shamsul.khan@unisa.edu.au

${ }^{\dagger}$ Mahjabeen Ahmad, formerly a Professor of Business Administration at the University of Dhaka, Bangladesh, is an Australia-based independent researcher and policy analyst. The key areas of her research are managerial communication and issues confronting Muslims living in the West. Email: mja@iba-du.edu
} 


\section{Shamsul Khan, Mahjabeen Ahmad}

\section{Introduction}

Two roads diverged in a wood, and I-

I took the one less travelled by,

I 22 And that has made all the difference.

The above lines from Robert Frost's poem, The Road Not Taken, perhaps mimics the choices that Muslims need to make as they grapple with the increasing hostility of the West that is being directed toward them and the religion they follow. ${ }^{1}$ The main argument of this article is that although it would not make all the difference, Muslims may benefit from engaging in some degree of introspection - the road less travelled-- to complement external or situational attribution - the path frequently taken. This article encourages soul-searching and calls for rational Muslim leadership at societal and community levels.

Whereas it is generally assumed that contemporary Islamophobia is directed at Muslims as a community, not Islam as a faith, ${ }^{2}$ we believe that it is both. What rattles ordinary Muslims is the propensity in the West to use freedom of speech-- a fundamental right that must be granted and protected in every society--to defame their religion and vilify them. What Muslims find totally unacceptable is the lack of respect the West displays and the double standards it often exercises by breaching international norms and trashing human rights with regard to Muslims and their countries. $^{3}$

While Muslims experience vulnerability at the discriminatory and overbearing treatment they receive at the hands of the West ${ }^{4}$ they also act in defiance as they cannot walk past the injustices, contempt, and deep-seated prejudices. The main argument of this article, however, is that killing and terrorising innocent people for avenging the wrong being meted out to the Muslims is certainly not the right path; on the contrary, the Muslim community needs to seek out avenues of redress that reflect the teachings of their great religion. In fact, the confused amalgamation of 'religious fervour and political objective' by some Muslims has resulted in desperate acts of violence on their part that have earned Islam a bad name. This article does not aim at analysing the causes or factors that have led to the current situation. It seeks to address the role of Muslims and their response to the escalation of present-day Islamophobia. It urges them to fight the menace of Islamophobia through actions that are based on justice, fairness, and unity, the values espoused in Islam, so that Muslims are no longer stigmatised by violent acts of a few and their religion is no longer defined by others.

Although prejudices against Muslims and Islam have been held by non-Muslims for centuries, ${ }^{5}$ this article refers to contemporary 'Islamophobia' which, for the purpose of this article, is any attitudes, beliefs, mind-set, or behaviours arising out of prejudice, antipathy, hostility, hatred, or discourse toward both Islam, the religion, and its followers, the Muslims. The term was in use among some Muslims living in the West to describe the discrimination and prejudices they were experiencing in their everyday life, an experience they attributed to the reality of being Muslims and living in non-Muslim or Muslim-minority countries. Even though "...Islam has been a factor in the definition of Western identity for centuries, consistently playing the role of 'rival' and theological/ideological 'other' ", ${ }_{6}^{6}$ it seems that the West still has a need to continually drum up a hysteria over Muslims lest the public wanders off. Islamophobia is deployed by the West to create and sustain the illusion of an 'existential threat' coming from the 'Islamic Other' and to conveniently position itself and construct its policies to deal with this 'threat'. Despite the strong presence of negative stereotype of Arabs in Western pop culture and its almost universal extension to all Muslims ${ }^{7}$, the truth is that Arab Muslims comprise only approximately $20 \%$ of the total global Muslim population while the rest $80 \%$ are non-Arabs. ${ }^{8}$

Viewing racism as coming in different forms, including cultural racism which is "a set of antagonistic or demeaning stereotypes based on alleged or real cultural traits", Tariq Modood notes 
“... The most important such form of cultural racism today is anti-Muslim racism, sometimes called Islamophobia". ${ }^{9}$ Thus, the markers of identification of communities of people clearly moved from just race, colour, nationality and national or ethnic origin to include religion and in the case of Muslims, their faith and culture and all that it entails. With most Muslims being non-white, Islamophobia also gets merged with racism; this then gets caught up in a vicious circle of immigration, integration, plurality, diversity, alien culture, and of course the ever-present threat and security issues. ${ }^{10}$

Since Muslims are not a race but followers of a universal faith across the racial and language divide, it does not help to describe attacks on them as 'racist attacks' for, in doing so, the specific concerns regarding Islamophobia are diluted with the more general issue of race. Covert attacks masked by often affected concerns over peripheral issues (such as, animal rights concern over the Muslim way of animal slaughter) may also slip under the radar.

Interestingly, the dominant emotion exhibited through Islamophobia is not fear, but hostility and hatred; this makes the term a misnomer. Often, this fear or hatred does not distinguish between Muslims and Islam. In other words, it is often not clear to many if it is the Muslim community towards which there are feelings of animosity and anxiety, or it is the culture, civilisation, or religion of Islam which attracts hostility or dread. Since some form of Islamophobia has been in existence in different forms through the centuries, it is evident that it has had 'a range of different causes and drivers', not least of which are 'Otherness', racist stereotyping, and xenophobia. The deeply embedded and negative public perception of Islam may be attributed to the oppositional binary viewpoint adopted by the West against it; “...binary conceptions not only depict all things oriental as 'other', but also define Islam as the 'other' religion to Christianity. With the 'other' constantly described as inferior, even barbaric, it is easily accepted by a Western audience that terrorism stems from Islam." 11 Of course, as Edward Said says, Islam is covered as "a one-sided activity that obscures what "we" $d o$, and highlights instead what Muslims and Arabs by their very flawed nature are". ${ }^{12}$

Islamophobia cannot be discussed without criticizing the role of media in shaping and defining people's perceptions with largely inaccurate and often wilful misrepresentations. A constant barrage of negative media coverage, often without the proper contexts, feeds the alarmist's views of Islam as barbaric and 'the Other'; particularly vulnerable are those who have little social contact with Muslims. In analysing the role of media in discursive traditions that have influenced Islamophobia, Jackson argues, "Typically, in portraying Muslims, the mainstream media has tended to employ frameworks centred on violence, threat, extremism, fanaticism and terrorism...". ${ }^{13}$ Pankaj Mishra succinctly expresses similar views in The Guardian, "Never perhaps in history has so much nonsense been so confidently peddled about a population as large and diverse as this planet's billion-plus Muslims. ...Almost every day newspaper columnists berate Islam, often couching their prejudice in the highly moral language of women's rights ...many respectable writers and intellectuals seem to have decided that selectively reading the Qur'an.... is the easiest and quickest way to figure it all out". ${ }^{14}$

Explaining the reason for the West's anti-Muslim bigotry, Edward Said notes that it is not the Muslims but the Western media and 'experts' who provide most of the commentary; they would comment on what meets the eye without choosing to go into deeper analyses of the causes. ${ }^{15}$

Muslims are subjected to both blasphemy, which is an attack on the religion, as well as religious vilification, which is an attack on the followers. It is worth noting that Muslims generally do not engage in slandering Christianity and Judaism; their grievance is against those followers of these religions who attack Muslims and their lands. While anti-Semitism is recognised as a crime in countries around the world including Muslim-majority country Turkey, not a single country in the West recognizes Islamophobia as such. It is in the interest of the West to recognize the damage they are doing to themselves through sustaining and promoting Islamophobia, which eventually translates into alienation among Muslims living in the West and, strengthens allegations that the West cannot be and do not wish to be the friends of the Muslims. 


\section{Shamsul Khan, Mahjabeen Ahmad}

Just as with any other religion, Islam, too, has varying degrees of adherence among its followers and has differences in interpretations of its teachings. Not all Muslims, notwithstanding the fact that they are believers in the most fundamental tenet of Islam-- the Oneness of God, practice Islam on a daily basis. When the West criticizes Islam, many do so without making a distinction between the religion and its followers; the teachings of Islam are painted with the same brush as the acts of its followers. Cognizance is accorded neither to the fact that Muslims are not a monolithic

I 24 group of people nor that the vast majority of the more than two billion Muslims worldwide are peace-loving and believe in co-existing with people who are dissimilar.

\section{Understanding Centrality of Faith Identity}

Although identity is a multifaceted construct, most Muslims emphasize their faith identity; this is not consonant with the norm in Western societies. Islam is central to the everyday life of a practicing Muslim, occupying a distinctive place, guiding action and behaviour, and shaping attitudes and experiences. While it is true that the Muslim faith is widespread covering many nations, colours, cultures, and languages, the common denominator has always been religion and a religious culture. Muslims are, therefore, a group that is defined mainly by reference to religion (all the more reason for Muslims to do the right thing by their faith).

A failure by non-Muslims to understand this centrality of faith translates into a failure to understand why not just attacks on Muslims but also attacks on Islam and its Prophet Muhammad ${ }^{16}$ is seen by Muslims as deeply offensive-in fact more--and particularly, why the ensuing hurt would often elicit strong reactions. Findings of an empirical research in $\mathrm{UK}^{17}$ show that the respondents, including Muslims, felt that ignorance and indifference towards religion was widely prevalent in society, that many did not understand the weight of religious values, and that this translated into lack of recognition and respect for religion.

The expectation and pressure on Muslims living in the West to separate their private religious identity from their public civic identity needs to be revisited. The UNDP reiterates the legitimacy of dual identity in its 2004 Human Development Report: "Individuals can and do have multiple identities that are complementary-ethnicity, language, religion and race as well as citizenship". ${ }^{18}$ Notwithstanding that the visibility of a Muslim identity in the West raises questions about loyalty and allegiance to the national identity instead of being recognised as a "valued (religious) identity", ${ }^{19}$ Muslims will not accept the 'demotion of religious identity' ${ }^{20}$ and would continue to fight for recognition and equality in the West, the like of which is granted to Christians and Jews even in secular countries.

Why is the perception among many in the West that the more you become secular, the more you are a 'good citizen', and conversely, the more you are a practicing Muslim, the less you are a 'good citizen'? If Muslims pander to Western liberal traditions, they are definitely 'good'; if not, they are fundamentalists. Strong Islamic identity is seen as indicative of divided loyalty by Western countries with a sizeable Muslim minority. Such Muslims are perceived as wanting to be more retentive of their different way of life and criticized for seeing themselves as Muslims first and not so much as citizens of their adopted countries. ${ }^{21}$

Charles Taylor's observations ${ }^{22}$ on recognition and identity sums up best the situation facing Muslims in the West: "Non recognition or misrecognition can inflict harm, can be a form of oppression, imprisoning someone in a false, distorted, and reduced mode of being". He goes on to say, "Due recognition is not just a courtesy we owe people. It is a vital human need."

Muslims in the West, too, have a responsibility to not only recognise and respect their dual identities (religious and national) but also carry out the associated obligations. This does not have to be a zero-sum game; instead, this could be an effective way to demand respect and recognition by the West and escape the entrapment that Taylor alludes to. 


\section{Secularism, and Fundamentalism and Islamism: A Case of Chalk and Cheese}

'Fundamentalism' or 'fundamentalist' is an oft-quoted flexible term with a high degree of negative connotation that is used in describing Muslims who are devout, vocal, or militant. Islamic fundamentalism is defined in the dictionary ${ }^{23}$ as "the belief or advocating of a conservative adherence to literal or traditional interpretations of the Qu'ran and the Sunnah, ${ }^{44}$ a far cry from the pejorative connotations so widely prevalent among people and societies. The use of the term 'fundamentalist' to describe people who resort to violence or terror against innocent people and happen to be Muslims is not helpful at all because of the underlying assumption that these Muslims find their justifications in the teachings of Islam in resorting to such acts to achieve their political goals. In secular societies and even among a few very 'cultural Muslims', ${ }^{25}$ this may appear plausible; the Qur'an, ${ }^{26}$ however, clearly prohibits taking of innocent lives. Also important to note is that the Qur'an does not support the use of force or compulsion in religion either; on the contrary it contains verses that offer clear evidence of supporting religious freedom as an individual choice. ${ }^{27}$

The utilisation of secularism to impede the presence and recognition of Islam and Muslims in the public space is a threat to plurality, equality, and freedom of religion. Contrary to popular misconception, 'secular' does not mean opposition to religion, rather, absence of a religious purpose. Pointing out that many of the laws, practices, and political thoughts in Europe are influenced by Christianity, Bhiku Parekh shows that "religion survives as culture" 28 and cites the example of treating Sundays and Christmas as public holidays.

The concept of secularism where religion is treated as an unnecessary appendage is untenable to a Muslim; unlike the relationship between some other religions and their adherents, Islam is an integral part of and central to a Muslim identity as has been stated earlier in this article. This is what Islamism means - that Islam is a way of life for practicing Muslims and cannot be put away or set aside or brought out only when a Muslim is in the privacy of his or her own home. However, Islamism remains a controversial term with strong overtones of negativity associated with it. 'In popular debate, the term Islamism has tended to become demonized -- as 'fundamentalism' was before it - to suggest an unacceptable and dangerous form of Islam, and Islamists of all kinds are often popularly regarded as potential terrorists". ${ }^{29}$ We believe that Muslims could use Islamism not only to become free from Western hegemony but also as a redemption mechanism to deal with the social, economic, and political inequalities that plague many Muslim countries.

Peter Jones' twin concepts ${ }^{30}$ of 'burdens of belief' and 'consequences of belief' could be employed to gain a useful perspective on the issue of pitting Islamism against secularism. He terms the intrinsic aspects of a belief as the 'burdens' (not necessarily an encumbrance or a problem) of a belief that are imposed by it and need to be fulfilled by its followers; on the other hand, the 'consequences' of a belief are the extrinsic aspects of a belief that are not regarded as essential requirements. Since many of the 'burdens' (obligation would perhaps be a better word) of their faith have a public manifestation (for example, congregational prayers or headscarves ${ }^{31}$ for women), Muslims living in the West often struggle to bear this 'burden' in private. When the external environment and institutions impinge on the carrying of the 'burden', such as an aged care system that does not understand and provide appropriate and culturally sensitive services, the 'consequences' of such a deficiency may become very serious for the practicing Muslim-- the 'consequence' being the unavailability of much needed appropriate services with its resultant impact on health and well-being. A supportive environment is needed so that Muslims do not have to bear in private all the 'burdens' of practicing their belief and suffer unfair 'consequences' in a system that claims to be multicultural, secular, and promoting diversity yet in reality favour the entrenched, long-established, and historically favoured religions. 


\title{
Shamsul Khan, Mahjabeen Ahmad
}

\section{False Analogies and More...}

Insidious terms such as 'Islamist, and 'jihadist' have entered the popular vocabulary such that reprehensible acts or ideologies are prefaced with these words. ${ }^{32}$ A group of Muslims perpetrating any extreme acts of violence is routinely termed jihadist or Islamist.

Jackson criticizes setting up such terms to form the discourse on terrorism, saying, "Crucially, in their textual usage these terms are often vaguely defined (if at all), yet culturally loaded and highly flexible in the way they are deployed." ${ }^{33}$ Sadly, Muslim countries and Muslim clerics and organisations in the West are culpable of inadvertently lending credence to this distortion by not speaking out enough or clarifying the actual meaning of these words.

One has to understand the doctrine of jihad before blaming Islam's teachings for the ills of the world although Muslims are largely to blame for the loose and frivolous interpretation of the concept of jihad to justify any attack that is carried out in the name of Islam.

\footnotetext{
"'Jihad' is a loaded term-and a concept that illustrates a deep gulf of miscommunication between Islam and the West. There are those in each community who see jihad as a 'clash of civilizations' - and act on those beliefs. But jihad literally means "exerted effort" to most Islamic scholars and Muslims, and represents a range of activities". ${ }^{34}$
}

Maher Hathout elucidates the various meanings of jihad: $:^{35}$

\begin{abstract}
“... The word jihad has a root verb: jahada, which in Arabic means exerting maximum effort or striving. The theological connotation is striving for betterment. Its major form is the struggle within oneself for self-improvement, elevation, purification, and getting closer to God. Another form is intellectual jihad, where the truth is offered to the hearts and minds of people through intellectual debate, wisdom, and dialogue, exposing the facts in the Quran in a clear and convincing way. Related to that is the concept of ijtihad, which is exerting maximum effort to derive solutions and rulings from the Quran and the teachings of Prophet Muhammad, to be implemented in different and dynamically changing contexts. Another form of jihad is using economic power to uplift the condition of the downtrodden and to finance the struggle for justice and liberation. Last, but not least, of the form of jihad is the physical form, where people actually fight against oppression".
\end{abstract}

Tariq Ramadan echoes a similar view when he says, “... The essence of jihad is the quest for peace, and qital [armed struggle] is, at times, the necessary path to peace". ${ }^{36}$

Islam has clear rules of engagement governed by a strict code of ethics. It lays down specific guidelines for the treatment of enemy combatants, protection of the innocent, the women, the children, and the elderly, even non-Muslim religious leaders, as well as environmental protection of the conquered land. This is not 'moderate Islam' or 'liberal Islam'; this is Islam. Jihad leads to true salvation; taking innocent lives or blowing oneself up based on incomplete or inaccurate understanding of the concept of jihad offers false salvation.

Islamists are not necessarily terrorists ${ }^{37}$ or support killing innocent people; not all terrorists are Muslims; and jihad is not terrorism. These distinctions are increasingly being blurred by the West and all Muslims are made to feel guilty by association of faith. Terrorism is not an ideology but a means to achieve desired goals. What is termed 'Islamist terrorism' or 'Islamic terrorism' 
and seen by the West as springing from an extreme interpretation of Islam is, in effect, motivated by a distorted view or misinterpretation of Islam ${ }^{38}$. Regrettably, some Muslims are also seen to make thoughtless use of such terms, including expressions such as 'radical Islam' or 'Islamic extremism', despite the fact that Islam is a religion of tolerance and a strong advocate of moderation.

\title{
Integration and 'Islam Engineering'
}

Immigration has changed the demographic landscape of the West. Largely immigrants, Muslims are in many ways culturally different to the West. Instead of viewing this difference through the lenses of equality, respect, and fairness just as other aspects of a person's identity such as culture, race, or language are to be treated, Muslims began to be viewed as a 'cultural other'. Too much hype is made about the cultural aspects of Muslim identity, such as appearance and dress, to the exclusion of discourses about the rich history and legacy of Islam and the many, many positive contributions that are still being made by Muslims. "A cultural 'other', the immigrant or a member of another community who does not share the same myth of common origin, is constructed as an alien and consequently as a potential 'enemy' who threatens 'our' national and cultural integrity and uniqueness". ${ }^{39}$ Bhikhu Parekh believes that, "Most contemporary societies are culturally diverse, but only some of them are multicultural or culturally plural". ${ }^{40}$ following: ${ }^{41}$

Article 27 of the UN International Covenant on Civil and Political Rights states the

\begin{abstract}
"In those States in which ethnic, religious or linguistic minorities exist, persons belonging to such minorities shall not be denied the right, in community with the other members of their group, to enjoy their own culture, to profess and practise their own religion, or to use their own language."
\end{abstract}

Integration needs to be seen as a dynamic and two-way process that "places demands on both receiving societies and the individuals and/or the communities concerned"42 - a marked departure from traditional thinking which puts all responsibilities of acculturation on the immigrants. Muslim community leaders must step forward to help Muslims in the West to integrate into the wider society. Needless to say, the first step toward this would have to be their acceptance in their countries of settlement. However, in order to make this happen, the host country needs to stop treating Muslims as a 'global peril' and start adopting openness in understanding and respecting their religion and culture, particularly the centrality of Islam in the everyday lives of Muslims. In a world dominated by an imperious Western political power, Muslims are having to fight not only for the recognition of their distinct identity in the West but also for acceptance as members of 'a recognised identity', such as members of the wider society or as full citizens having equal rights and respect. While focussing on institutional recognition, it is important that the wider society also accords this recognition, acceptance, and respect.

While Muslims, just like any other community, need to accommodate the cultural practices of the broader society so long as these are not discordant with their faith beliefs and practices, they cannot be expected to negotiate their religious identity and those aspects of life that are considered essential to upholding their religious and moral values. In a multicultural society, Muslims have a right to an open, non-judgemental, and supportive environment that understands and supports their needs so long these needs are not incongruent with Western values.

Tariq Modood zeroes in on one of the foremost shifts toward plurality in a diverse society when he observes, “... one of the current conceptions of equality is a difference-affirming equality, with related notions of respect, recognition and identity...." ${ }^{43}$ The right to be different is passionately defended in the West, not so when it comes to Muslim issues such as headscarf. Their 


\section{Shamsul Khan, Mahjabeen Ahmad}

calls for accommodating, to the extent possible, their need for public funding of mosques or halal butchers are alleged to be demands for 'preferential treatment' and thus elicit, at times, vociferous negative campaigns by government and civil societies, whereas these could be positively viewed as avenues for supporting diversity on legitimate issues.

Superficial or outwardly visible symbols such as dress or food habits cannot be an adequate measure of integration into the wider society. Muslims are often accused of rejecting Western lifestyles and values, thereby creating a parallel society in their adopted countries ${ }^{44}$ Contrast this with the 'religious exemption' awarded to Sikh men in many secular Western countries such as the United Kingdom and Australia, from taking off their turbans to wear crash helmets when riding motorbikes or cycles. Needless to say, the value of such accommodation for individuals also lies in its symbolism - recognition of, and respect for, faith identity of a group of people.

Granting people cultural liberty is one of the ways to move towards securing differenceaffirming equality. Cultural liberty is "the capability of people to live and be what they choose, with adequate opportunity to consider other options" ${ }^{45}$ As the UNDP states in very strong terms: ${ }^{46}$ "Cultural liberty is a vital part of human development because being able to choose one's identitywho one is-without losing the respect of others or being excluded from other choices is important in leading a full life. People want the freedom to practice their religion openly, to speak their language, to celebrate their ethnic or religious heritage without fear of ridicule or punishment or diminished opportunity. People want the freedom to participate in society without having to slip off their chosen cultural moorings."

The UNDP terms cultural liberty as a human right and, thus, an important aspect of human development that needs the support of governments and societies. At the same time, it warns against cultural exclusion that "comes from a simple lack of recognition or respect for the culture and heritage of people — or from some cultures being considered inferior, primitive or uncivilized". ${ }^{47}$ The UNDP Report refers to two forms of cultural exclusion that are found to be practiced in the world: living mode exclusion and participation exclusion. There is a need for the West to end these two forms of cultural exclusion that Muslims may be made to suffer; Muslims, on the other hand, need to pursue legitimate ways to come out of the participation exclusion.

Relentless negative depiction of Muslims and Islam in public discourse fuels concerns about the supposed inability of Muslims, with their high degree of religiosity, to acculturate in the largely secular Western environment. The fact is, in order to live in harmony in their adopted countries in the West, Muslims try to reconcile these two apparently incompatible facets. Muslims value their composite or 'hyphenated' identities, such as Australian-Muslim or British-Muslim or AmericanMuslim. This is akin to what Waleed Aly referred to as 'dual authenticity'. ${ }^{48}$ The question is not of 'either or' but one of trying to find the right balance between two identities. A Gallup World PollThinkForum study ${ }^{49}$ on Muslim residents in three major European cities demonstrated that while religion remains an important part of Muslim identity, followers of the Islamic faith in these places also identify strongly with the country they live in. The findings contradicted charges of 'cultural separatism' against Muslims. The fact that they can have 'dual authenticity' even while having dual identity was a significant finding of this study. ${ }^{50}$

Bhiku Parekh also offers strong recognition to Muslims as a law-abiding, patriotic, and appreciative community in their countries of settlement in the West. ${ }^{51}$

Undeniably, Muslims--the convenient scapegoat and the favourite folk devil ${ }^{52}$ of the West-are routinely and savagely criticized for having an 'alien culture'; the West, however, would profit much from reining in gambling, alcohol and drugs, indiscriminate sexual misdemeanour and other vices that plague their families and society and that have been prohibited in Islam. Focusing on the negative influence of culture on religion, Eckersley asserts that materialism and individualism, especially in combination, are two powerful cultural factors that work against spirituality in Western societies. He says, "Cultural messages can create tension, conflict and confusion within individuals when they run counter to religious beliefs and teachings, making it harder to integrate religion into their lives.... Cultures can "hollow out" the spiritual content of religion and fill it, instead, with other things, including materialism" ${ }^{53}$ Eckersley decries the detrimental effects on 
health and wellbeing brought about by the modern Western culture that accentuates personal consumption and self-gratification, and he, therefore, emphasises the role of spirituality to offset such negative consequences.

Certain labels, assumptions, terms, and narratives used in political debates and in daily conversations in the West, paint a less than flattering picture of Muslims. Adjectives such as 'moderate' or 'progressive' or 'liberal' when ascribed to a Muslim insinuates that the antonyms of these words are also applicable for other Muslims. How many times would one use these words to describe a Christian, a Jew, a Buddhist,${ }^{54}$ a Sikh, or a Hindu? As long as Muslims are treated as the bogeyman and the pariah, Western claims of egalitarianism and inclusion would remain just thatclaims.

As pre-emptive actions, ostensibly to thwart the rise of 'Islamic extremism', the Western governments are adopting overt and covert interventionist policies and approaches to tame Islam's presence in their public sphere. Much of this misplaced effort needs to be directed at separating reality from the smokescreen in political discourses so that the disassociation of extremism and terrorism from Islam and Muslims in the public psyche may be given a chance.

"For many government leaders today, the question is no longer how to help Muslims feel at home in foreign societies, but how to ensure that these societies produce the right kind of Muslims". ${ }^{55}$ Such actions, amounting to 'overhauling' of Islam, do not engage with the Muslim community; instead, these unhelpful interventions clearly target Muslims and/or Islam as 'the problem'. They attempt to promote and develop a more 'progressive Islam/Muslim', a 'moderate Islam/Muslim', or a 'liberal Islam/Muslim'. Where is then the ubiquitous Western claim of churchstate divide? Islam is a religion, not an 'ideology' that can be tweaked in favour of making it acceptable to certain groups of people or certain societies. Muslims have a right to protest and repel the implicit argument inherent in this approach, which is, that their religion is deficient and needs to be fixed. Such approach begs the question: Is 'Islamness/Muslimness' to be measured on a scale? Who measures it and why and how is it measured? Where on the scale does a devout Muslim, or for that matter, a 'cultural Muslim' fit in? This whole nomenclature seems absurd.

Similarly, while discourses are needed on responsible citizenship that would help Muslims in the West to understand the different environment they live in and to engage in it honourably and productively, the engineering of British Islam, American Islam, French Islam, Australian Islam and the like cannot bring any good. It is as if the West would like to dictate the terms and conditions regarding their faith that Muslims living in the West ought to abide by. Although it is difficult to have a "single correct, or 'proper', interpretation of any religion", ${ }^{56}$ such 'Islam engineering' will be detrimental to both Muslims and the West as it would debase and distort the religion even more, create new divisions and conflicts among Muslims or intensify existing ones, and increase suspicion about the West.

\section{Just Exercising Freedom of Expression or Also Taking the Opportunity to Spew Hatred?}

Talal Asad makes clear the divide between the sacred and the secular when he says, "It becomes difficult for the secular liberal to understand the passion that informs those for whom, rightly or wrongly, it is impossible to remain silent when confronted with blasphemy, those for whom blasphemy is neither "freedom of speech" nor the challenge of a new truth but something that seeks to disrupt a living relationship". ${ }^{57} \mathrm{He}$ also refers to the "obsessive need to repeat again and again the words and images that secularists know will be regarded by the pious with horror". ${ }^{58}$

The proclivity and ability of those in the West to constantly attack Islam may be a show of power or deliberate provocation stemming from hatred. Putting on blinkers and seeing the world in only black and white as in 'them' (Muslims) versus 'us' (the West) makes some to revel in unleashing vitriolic attacks on the Prophet of Islam, his religion, and his followers. Islam is bashed, primarily in the media but, also in the arts and popular culture, at dinner tables, in the streets, in 


\section{Shamsul Khan, Mahjabeen Ahmad}

political discourses, even among the academia, all in the name of essential and healthy debate and, of course, freedom of expression. Morey and Yaqin maintain that, "... it would be naïve in the extreme not to recognize that the incessant demonization of Muslims and their cultural practices by those with access to the major vehicles of public discourse in the West has indirectly given a green light to prejudice and vigilantism". ${ }^{59}$ As Edward Said rightly points out, "A core of "experts" on the Islamic world has grown to prominence, and during a crisis they are brought out to pontificate on I 30 formulaic ideas about Islam on news programs or talk shows.... what is said about the Muslim mind, or character, or religion, or culture as a whole cannot now be said in mainstream discussion about Africans, Jews, other Orientals, or Asians". ${ }^{60}$

Freedom of expression cannot be absolute but must be tempered with responsibility; not surprisingly, unbridled freedom of expression and respect for religion are on a collision course. Freedom of expression as an enshrined constitutional right is fashioned by the West and mirrors its notion of what constitutes fairness. Ironically, all norms of decency and respect are suspended when it is used to disparage Muslims and stigmatize Islam. The West refuses to understand the religious beliefs of Muslims surrounding any depiction or imagery of God and His Prophets that makes such acts sacrilegious or blasphemous. Any criticism of their Prophet is an assault on their religious sensibilities, an affront on the inviolable areas of their faith. This lack of basic understanding about Islamic culture makes it possible for the West to see the Muslim uproar over Salman Rushdie's controversial book The Satanic Verses ${ }^{61}$ or the infamous Danish cartoons in the Danish newspaper Jyllands-Posten ${ }^{62}$ and many such expressions of ridicule as a lot of hullabaloo. ${ }^{63}$ Just recall the vigorous defence of freedom of expression on the international stage when Muslims around the globe strongly protested over these depictions.

Peter Jones captures and seeks to understand the battle between freedom of expression and the deep offence it may sometimes cause when he remarks: “... the reality and unpleasantness of offence can be distinguished from the truth of the beliefs upon which it depends. We therefore have reason to take account of belief-based offence, even though we reject the beliefs upon which it is based. Muslims may complain about the wrongness of the [Danish] cartoons rather than about the offence that the cartoons cause them to feel. But non-Muslims can and should take account of the offence that Muslims feel rather than the wrongness of which Muslims complain." 64

The line between profanity and sacred is different for Muslims and the West such that blasphemy is a religious concept to the Muslims but to the West it is also a legal, cultural, or secular concept. The New York Times reported about a German opera house production of a Mozart opera that includes a scene, not part of the original piece but added by the director, depicting the severed head of the Prophet Muhammad. ${ }^{65}$ Although defended by many in the political and cultural arena as part of artistic freedom, this depiction is yet another example of pushing boundaries to deliberately provoke hatred and violence by abusing freedom of expression. Such demonstration of constant disrespect and intolerance will eventually give birth to anger that would spill over to the streets. ${ }^{66}$

Another example of how the line between profanity and comedy are obliterated is when comedian Ricky Gervais brought a Bible on his stand-up show Ricky Gervais Live: Animals on Australian $\mathrm{TV}^{67}$ where he made fun of its contents, and the audience clapped. Muslims would regard such behaviour sacrilegious. The Sydney Morning Herald writes of Gervais: "All over Twitter he's the arch atheist, trolling the faithful with glee" ${ }^{68}$ In terms of scale and intensity, the protests and condemnation across the Muslim world to the Danish cartoon, The Satanic Verses, and the International Burn a Qur'an Day ${ }^{69}$ differed significantly on both counts to the response in the West to an exhibition in Russia that portrayed Jesus Christ as Mickey Mouse ${ }^{70}$ or a painting of Mary spanking the Christ Child ${ }^{71}$ in one of the leading art museums in the world.

The standoff is between two opposing views that seem light years away from each other: the West's support of absolute freedom of expression that may include mockery or ridicule and the Muslim insistence on setting limits to protect against defamation of religion. Muslims are not opposed to freedom of expression per se but they have a problem supporting unlimited use of such freedom that attack religious sensibilities. Much has been written and debated but the divergent 
positions are nowhere near converging. Interestingly, the West adopts a double standard when religion, particularly Islam, is fair game but anti-Semite or anti-gay comments are off-limits. Since no Western society is homogenous but is composed of people from many diverse backgrounds, sensibility toward others is an essential precondition for harmony.

This 'sinister shield' of freedom of expression with little or no adequate safeguards to protect religious beliefs needs to be revisited. If not, there is a very real danger of escalation of more provocative portrayals. Many countries have anti-discrimination Acts covering sex, sexuality, race, and disability but when it comes to another emotive issue-religion--even discussions to put in explicit legal safeguards become anathema to the secular society and the 'standard-bearers' of freedom of expression. The result: Muslims becoming "unwilling 'victims' of another's freedom". ${ }^{72}$ If one's freedom is another's fetters, parameters for that freedom may need to be set since "...If some have to pay the price for the use that others make of their freedom, including their freedom of belief, the legitimacy of that freedom is very much in doubt". ${ }^{73}$ Western insistence to protect the individual and not necessarily his or her belief runs counter to the Muslim world's demand to protect religion as well. The idea, that if something is not unlawful it must be alright, also needs to be challenged. Indeed, Peter Jones postulates a wider perspective that makes a public conduct that is within the parameters of law still likely to require evaluation through critical appraisals as "social norms governing acceptable expression are likely to be at least as significant as the letter of law" ${ }^{74}$

\section{Disenchantment with the West: The Far Enemy}

A new discourse is needed to clear the name of Islam and to reposition Muslims; clearly this is not happening as the popular discourse has been overtaken by a simplistic, prejudiced, and erroneous conclusion that Islam is the problem. Tariq Modood remarks that not only have Muslims in the EU become "the single largest group of those who are the source of public anxieties" 75 but also that Muslims "have become a focus of national concern and debate in many countries". ${ }^{76}$

A determination to overcome obscurantism would encourage one to enquire if those Muslims who engage in attacking innocent people are only motivated by their own interpretation of their religion or there are deeper, underlying historical forces and political reasons at play. Those who are biased against Islam and Muslims would not make the causal connection between some acts of terror by Muslims--undoubtedly reprehensible--and the injustice, humiliation, discrimination, social scrutiny, surveillance, victimisation, or oppression that Muslims endure at the hands of the West or on account of biased Western foreign policies or actions and/or support for actions that are damaging to peace, stability, and prosperity in Muslim countries. Jackson affirms this point in his critique of 'Islamic terrorism' discourse when he says, "In short, in-depth qualitative studies suggest that terrorism is always local; that is, it is driven by identifiable political grievances and issues specific to particular societies and locales." ${ }^{77}$ One can see an innate contradiction when the West uses troops and war machinery to kill innocent people in the name of liberation and safeguarding or protecting democracy, yet labels those Muslims fighting injustice and oppression as extremists or terrorists. This is doublespeak. The scourge of contemporary terrorism may well be made out to be linked to Muslims but the West has to acknowledge its role in fomenting extreme views through discriminating, marginalising, and vilifying the former.

The zeal that accompanies Western attacks on Muslim lands and people in the name of protecting democracy and human rights, although seen by many as a form of state violence, is apparently missing in the case of the Rohingyas ${ }^{78}$, dubbed by the United Nations as one of the world's most persecuted people and also one of the most forgotten.

The US military's flouting of the Geneva Conventions by carrying out gruesome torture and degradation on detainees in the notorious Abu Ghraib prison facility during the invasion of Iraq had made sordid headlines around the world. Despite the Abu Ghraib chapter becoming a microcosm of the West's hatred of Muslims, the US soldiers' non-Muslim religious backgrounds did not merit mention in the press. Perhaps rightly so, because none of the revealed religions 


\section{Shamsul Khan, Mahjabeen Ahmad}

including Christianity condone such brutality, torture, or cruelty, and importantly, unlike many Muslim extremists, the perpetrators of this unspeakable torture regimen in Iraq did not use their religion to justify their barbarism. Arguably, the US personnel carried out these despicable abuses on the detainees as Iraq is a Muslim country and the victims were Muslims; no one, by any stretch of imagination, can catch the US in this act in any Western country. This would not be because of a country being a US ally; many Muslim countries are US allies, too. In the eyes of many Muslims, I 32 herein lays a clear exhibition of hatred toward them.

The disturbing escalation of child sexual abuse cases by the Catholic priests or the regular insane murders on American streets, homes, schools, and movie theatres by disgruntled individuals have not led anyone to question the teachings of Christianity or the values of Christians or the West. However, images of the entire Muslim community as a 'global menace' and Islam as 'the culprit' or 'the demon' is constructed based on acts of a minority few and then magnified and circulated, repeated, and used. ${ }^{79}$

\section{Lure of False Salvation and a Case of Shooting Oneself in the Foot}

Extremism must evoke a zero-tolerance approach regardless of who the perpetrators are. Any act of injustice is irreconcilable with the values in Islam that strictly prohibits suicide and all kinds and forms of aggression and violence, except in self-defence. Interestingly, there is no evidence that suicide bombers are glorified; on the contrary, they are on the 'fringes' and their method of 'salvation' is rejected by the vast majority of Muslims as is confirmed in a study ${ }^{80}$ by Pew Research Centre. Not surprisingly, these voices are under-reported in the public discourses in the West.

When Muslims engage in internecine conflicts and violence, particularly along ethnic or sectarian lines, it challenges the oft-held perception that Islam-- the core of Muslim identity-is the prime identity for every Muslim. Muslim transgressors, and that includes a few clerics with extremist views, must realise that they do not serve Islam or their $u_{m m a h}{ }^{81}$ through preaching about, or carrying out acts of, intolerance and violence. Any vitriol and violence perpetrated and justified in the name of Islam must be spurned by Muslims; an extremist Muslim can do greater harm to the reputation of Islam than can ever be done by any non-Muslim. Yusuf Islam, the former pop star Cat Stevens, deemed it his personal duty to "try to reduce the demonisation of a religion that is still appallingly misrepresented" through an article in the The Independent ${ }^{82}$ Ruefully commenting in the aftermath of 9/11 on the damage inflicted on Islam's reputation as a peaceful religion, he laments, "Not only did terrorists hijack planes and destroy life, they also hijacked the beautiful religion of Islam". Commenting on the long-term effects of an act of terror on fellow Muslims living in the West, Murtaza Hussain says, "The real damage done to the social fabric by such attacks is the erosion of trust and respect between society at large and its Muslim minorities." ${ }^{\text {"3 }}$

One may argue the reasons why so much of volatility and conflict exist in the Muslim world. These violent acts are more likely responses to current local political realities although, on a much smaller scale, a few may be demonstrations of loyalty to the ummah. Although a feature not unique to Muslim-majority countries, much of the economic and social deprivation, and disempowerment marked by lower indices of political rights among the common people, in these countries is caused by autocratic, tyrannical, and dictatorial governments, many of them abetted or propped up by Western powers and policies. Finding themselves on the fringes, a section of the marginalised people may become disillusioned and frustrated and resort to acts that may not find legitimacy in their religious teachings. The rise and use of political religion of any persuasion can be linked to inequalities and injustices and not to the teachings of the religion per se, a fact that seems lost on many in the West. Some question the ability of Islam to accommodate democratic norms; till date, no consistent evidence has been found to link Islam with autocracy. ${ }^{84}$

The determination of the extremist few among Muslims is a direct result of, among other things, the West's deep disrespect and injustice; the extremists' own distorted, deficient, and faulty knowledge about the great religion of Islam; the deep divisions among the Muslim ummah; and a 
failure as well as reluctance to rise above vested interests and return to the enlightened guidance provided in the Qur'an and the Sunnah. Every time, he shouts "Allahu Akbar!" (in Arabic, God is Great, a declaration by every Muslim during prayers) when pulling the trigger to kill an innocent person, the terrorist Muslim forgets that he is incurring extreme wrath of Allah and making it harder for non-Muslims to separate his religion from his action. The mass abduction of more than 200 schoolgirls in April 2014 by Nigeria's militant insurgency group Boko Haram (which means "Western education is forbidden" in the Hausa language) is one of the most recent examples of extreme ignorance of Islam's teachings and values and is a portrayal of unspeakable barbarism on the part of these insurgents.

Needless to say, such extremism has encouraged an almost incessant flow of hateful discourse against Islam and its followers, further endangering Muslim--non-Muslim relations and fuelling animosity of the West. The leading religion stories of 2011 in the US media involved tensions and controversies over Islam or Muslims in the U.S. or abroad. It shows an upward trend over the last several years. A Pew Research Centre analysis of religion coverage indicates that interest in religion tends to be profoundly event-driven. ${ }^{85}$ Technological advancement, the internet, blogosphere, and globalisation have all helped to transform a single act of terrorism into a Lernaean Hydra.

Every time a disenfranchised or aggrieved Muslim resorts to harming innocent people, the Pareto principle goes to work immediately against his faith and innocent fellow Muslims. The Boston Marathon bombings has helped to push the percentage of Americans who say Islam is more likely than any other religion to encourage violence among its followers, from $25 \%$ in 2002 to $42 \%$ less than a month after the Boston bombing in April 2013. ${ }^{86}$

Islamophobia, with its attendant discrimination, may lead to both exclusion and selfexclusion of Muslims in the West, particularly its youth, with obvious undesirable consequences in terms of identity, self-esteem, and social integration. Opportunities may then arise for the extremists to attract and recruit these disenchanted and disaffected Muslims. Another serious fallout that is imperative to address is the possibility that the young and the very young Muslims may experience an erosion of respect for their religion; after all, it is very likely that those being brought up amidst a mass frenzy against Islam and Muslims may become bewildered and may seek to question the teachings of Islam when it is being continually distorted and wrongly portrayed by the ignorant among their own and by those in the West who seek to gain from whipping up Islamophobia.

\section{Overcoming Internal Demons}

Islam does not choke off human agency but provides room for individual judgment and reasoning and outlines consequences of judgment calls. In many instances, Muslims need to pause before condemning the West for making unfair criticisms and judgements against them and their religion when they themselves have not understood what constitutes Islam. Being guilty of culpable ignorance, they practice and display what is definitely not in the Qur'an and Sunnah. Islam is a 'stranger in its own land' is how the Islamic theologian Yusuf al-Qaradawi ${ }^{87}$ describes the lack of adherence to the teachings of Islam in some Muslim countries.

The guaranteed and enduring fallout from thoughtless comments or brutal acts by Muslims is that the great religion of Islam is maligned and the entire community of Muslims stands trial and have to defend their faith and culture against charges of intolerance, bigotry, fundamentalism, terrorism, extremism and so much more that are falsely ascribed to it. Not only this fallout serves the interests of the zealots on the other side, more dangerously it also helps shape the attitudes and behaviours of those who are ignorant about Islam. Further, it exposes and widens the cultural and religious fault-lines and serves to strengthen pre-existing prejudices on both sides.

Since many verses of the Qur'an were revealed as the situations had warranted, it is imperative to understand those verses in their proper contexts. Therefore, one should be 


\section{Shamsul Khan, Mahjabeen Ahmad}

intellectually honest in reading and interpreting the Qur'an just as in applying its message without taking verses out of context. One must be prudent enough to want to understand the broader historical, societal and cultural contexts in which many of the verses in the Qur'an were revealed, such as verses that refer to fighting and killing, before wilfully, impatiently or carelessly drawing a line under a particular verse. One must also beware of distorting Sunnah. This applies to those who practice Islam, those who are 'nominal' or 'cultural' Muslims, and importantly, those who claim to

I 34 be 'experts' on Islam and/or Muslims.

\section{Sins of Commission and Omission: What Happened to the Ummah Today?}

The concept of Muslim ummah or Muslim universalism is about how local Muslims respond to situations in distant lands. Springing from concern for collective welfare, this response is to be united and based on wise choices, eschewing all forms of violence against the innocent and not transgressing limits set in the Qur'an and Sunnah. The question then arises: should not this transnational feeling for fellow Muslims also be channelled into realising how one act of terror may have a snow-balling effect on the hearts and minds of people which may get translated into widespread fear and hatred for Islam and innocent Muslims elsewhere?

The atrocities that are being committed in the Muslim world along sectarian or ethnic lines, such as in Syria or Iraq, lends so much power to Fred Halliday's observation that “... All those who are Muslims certainly consider Islam as part of their identity. Yet these commonalities of faith, practice and solidarity are not the whole story. Islam may, in some contexts, be the prime form of political and social identity, but it is never the sole form and is often not the primary one: within Muslim societies divisions of ethnicity matter as much and often more than a shared religious identity; this is equally so in emigration" ${ }^{88}$ Notwithstanding doctrinal differences about 1300 years ago that led to Muslims being divided into two main sects, the Sunnis (about 80 per cent of worldwide Muslims today) and the Shiites (about 15-20 per cent), they have largely coexisted peacefully. However, over the centuries there have been occasional deadly sectarian wars waged against each other and in recent years, this religious division has become one of the main drivers in the escalation of violence in the Middle-east. This is not only internecine but it also offers pretexts and opportunities for external forces to enter the fray. Why does the Muslim world have to look to the West to help them solve their problems? Why does any hope of halting, if not stopping the carnage in Syria, and now Iraq after part of the country was overrun by ISIS ${ }^{89}$, dependent on the West, and not on the Arab League or the OIC? It is a sad fact that Muslims cannot often count on Muslim rulers to raise a united voice and take united actions against any oppression of the ummah. Some of these Muslim governments are willing pawns on the geo-political chessboard.

Remarking on tensions and conflicts between Muslims and non-Muslims, Halliday says, "Alliance and cooperation have been as prevalent as conflict: the Kaiser sought to lead Muslims in World War I, the Soviet Union backed jihad and national liberation from the 1920s to the 1970s, the CIA funded the Afghan mujahidin in the 1980s". ${ }^{90}$ From a different perspective, these may not signify alliances and cooperation to protect or further the interests of Muslims, but consequences of a disunited and divided Muslim ummah playing into the hands of Western powers.

Muslims today are a house divided unto itself having to fight the near enemy or internal demons and the far enemy or external oppressors. Muslim ummah today is a shadow of what it used to be and what it needs to be. The absence of the primacy of the Muslim identity is to blame for many of the ills being perpetrated in the name of Islam. Regrettably, divisions of ethnicity and even deeper divisions of sects often supersede the commonalities of the ummah thus pushing Muslims down a slippery slope. What an incredible downward spiral from the early days of Islam when the Arabian Peninsula, made up of numerous clans and tribes, frequently at war with one another, could transcend their divisions and unite under the umbrella of Islam!

Fred Halliday ${ }^{91}$ may have postulated about the selected universality of the Muslim identity; however, when Muslims gravitate toward their Muslim identity or makes it the primary identity, 
they do so not out of exigency, contingency, or convenience but because of the philosophy of ummah that mobilises them with a sense of belonging, strong identity, communality, and strength. This is borne out by Amin Maalouf's ruminations about common identity quoted by Siobhán McPhee $^{92}:$ "... The affiliation that is a cause - colour, religion, language, class - invades the whole identity. Those who share it feel solidarity; they gather together, mobilise, encourage each other and take sides. For those, affirming their identity becomes inevitably an act of courage, an act of liberation". ${ }^{93}$

\section{Time for introspection}

The widely prevalent and gravely erroneous correlation between Islam and terrorism needs to inform vigorous debates among Muslims as to how to deal with injustices and discrimination meted out not only by the West but also by their own leaders. They would need to discard the mentality of 'victimhood' and re-evaluate their responses to their detractors so that the systematic and sustained denigration of Muslims can be dealt with in a calm, rational, and responsible manner.

The global Muslim community today "face the challenge of reorganizing and redefining themselves within the context of a world order that has been arranged by others". ${ }^{94}$ However, Muslims should avoid the "deadening pessimism ${ }^{95}$, to borrow the term from Martin Luther King, $\mathrm{Jr}$., that Islamophobia is here to stay.

How, then, should Muslims respond to win back dignity, assertiveness, and supremacy? The direction to take is the core argument of this article: Muslims must not help to sustain Islamophobia through actions prohibited in Islam and which provides fodder to the critics. Muslims must provide the right interpretative framework through which they and their religion can be viewed by others. They need to be able to differentiate between constructive and destructive ways of confronting Islamophobia, not just through 'political Islamism' which offers a route to politically mobilise Muslims just what 'black nationalism' had done to gain 'black power', but also mobilise at the community level. Muslims would need to define their collective goals and work toward them in a concerted, unified, peaceful, yet effective manner. In light of misinterpretation of political Islam by Muslims and its misrepresentation by the West, there is a genuine need for serious intellectual debate on understanding and reforming this concept.

The widespread misrepresentation of Muslims needs to be counteracted by opinion leaders and anyone with a keen sense of justice and fairness. Muslim families, community leaders, and Imams are the key drivers on the ground to correct misperceptions and guide their 'flock'. The role of Muslim community leaders and Imams are profoundly important to shape views and approaches just as the role of political leaders, academics, commentators, and the general media is in offering alternative views on Islam and Muslims. Writing on political mobilization and claim-making over Islam, Cinalli and Giugni ${ }^{96}$ affirm that Muslim leaders and organizations "have the highest legitimacy - in terms of institutional access and public discourse-to speak on behalf of their communities". These actors also need to improve cultural and intellectual relations with nonMuslims with the purpose of rooting out prejudices and misconceptions and building bridges.

The Muslim diaspora can engage in a host of ways as part of ummah to better serve the cause of Islam: participate in the wider society, access power structure through civic participation, develop political maturity, respect other communities, recognise that living in the West would require reasonable accommodation, speak out, get ready to engage in issues of injustice and hatred in its full context, encourage reasoned discussion and informed debate, set examples, build social capital in terms of education, and recruit educated and trained Imams who appreciate the tensions of living in the West and who can address the concerns of Muslims caught between two cultures and identities. In the West, the Muslim community may have many organizations, even mosques, set up along ethnic lines that are often beset by undercurrents of turf war and rivalry and does not help much to forge solidarity among the Muslim diaspora who, as it is, typically come from diverse backgrounds. 


\section{Shamsul Khan, Mahjabeen Ahmad}

There seems to be a lack of religious leadership among Muslims living both in Muslimmajority countries and in the West. With regard to the former, a religious leader may be issuing a fatwa without having proper theological education. A well-structured religious literacy program would not only better equip Muslims to denounce and eschew extremism and distortions of faith but would also help them to effectively combat the negative discourses and disparaging treatment of Muslims. There is a lot of confusion and contradictions surrounding what constitute faith

I 36 practices and what are cultural practices. Islamic theologians and scholars need to urgently address and clarify these issues; it would then help many Muslims to gain confident knowledge and distinguish between truth and error and, consequently, practice and portray true Islam. This is also needed to connect with and rightly guide the second and subsequent generations of Muslims born and educated in the West on issues that earlier generations need not have to tackle with; ".... lack of religious literacy and education appears to be a common feature among those that are drawn to extremist groups. The most vulnerable are those who are religious novices exploring their faith for the first time as they are not in a position to objectively evaluate whether the radical group represents an accurate understanding of Islam". ${ }^{97}$

Muslims would need to speak for themselves. But one needs to be cautious about some Muslim exponents who toe the mainstream line and try to lend credence to the dominant, yet faulty, discourses on Islam and Muslims. Extremists and detractors of Islam have taken control of the popular and academic narrative; this control must be taken away from them by Muslim scholars, community leaders, and other opinion makers who have a huge responsibility to fight the stereotypes, demystify all that are foggy about Islam both among Muslims and non-Muslims, and help Muslims rediscover their true identity. The war on Islamophobia must be fought with wisdom and courage on the intellectual front primarily by them and this discourse cannot be allowed to be controlled through radical ideologies and terrorist activities of the desperate few or the views of the largely hostile, ignorant, and biased West.

\section{Concluding remarks}

The above discussion is in no way intended to absolve the West of its central role in demonizing Islam and often forcing Muslims to retaliate against specific Western policies affecting them. This discussion is intended to advocate for a different approach in dealing with the broader issues surrounding Islamophobia. In these challenging and difficult times, binary thinking patterns that promote stereotypical commonplace attitudes will have to give way to openness, communication, and dialogue carried out in good faith to search for shared values and establish common grounds; this must be a two-way responsibility of the Muslims and the West.

Martin Luther King's immortal words of wisdom and inspiration echo as Muslims are faced with a choice to travel down a new road, "...I will still raise my voice against riots and violence because I don't think that it solves the problem. I think that it only tends to intensify the fears of the white community while relieving the guilt. I think it is impractical because an old eye-for-an-eye philosophy can end up leaving everybody blind, and I think, in the final analysis, it is impractical because violence begets violence, hatred begets hatred. It's all a descending spiral ending ultimately in destruction for all too many. [So] I am still convinced the greatest thrust can be made through militant non-violence. But in condemning violence it would be an act of irresponsibility not to be as strong in condemning the conditions in our society that cause people to feel so angry that they have no alternative but to engage in riots". ${ }^{98}$

As Islam and the West continue to come into close contact by virtue of globalisation, they are confronted with much ignorance about each other, resulting in confrontations and fear as part of lived realities on the ground. The endless interest in Islam and Muslims seems overwhelmingly to stem from the association with terrorism that the West makes. Since terrorism has contributed a lot to wholesale, unfair, and unprecedented public criticism of Islam, it is an obligation for all 
Muslims to offer the West the opportunity to witness and experience the true nature of Islam- that of peace, tolerance, moderation, and compassion.

\footnotetext{
${ }^{1}$ For elaborations on such hostility, see Z. Strabac and O. Listhaug, "Anti-Muslim Prejudice in Europe: A Multilevel Analysis of Survey Data From 30 Countries", Social Science Research, 37(1) (2008, pp. 268286) and G. Marranci, "Multiculturalism, Islam and the Clash of Civilisations Theory: Rethinking Islamophobia", Culture and Religion, 5(1) (2004, pp. 105-117).

${ }^{2}$ See, for example, R. A. D. Bloul, "Anti-discrimination Laws, Islamophobia, and Ethnicization of Muslim Identities in Europe and Australia”, Journal of Muslim Minority Affairs, 28, No. (1) (2008, pp. 7-25).

${ }^{3}$ Manifestations of this can be found in relentless drone attacks in Pakistan, illegal invasions of Muslim lands, incarcerations without charges, the Guantanamo prison camp, and in marked indifference of the West to the Israeli occupations of the Palestinian territories.

${ }^{4}$ For an exposition of such discrimination, see Ö. Orhun, "Intolerance and Discrimination against Muslims (Islamophobia)", "Security \& Human Rights", 20(3) (2009, pp. 192-200).

${ }^{5}$ For an interesting analysis of such deep-rooted prejudices, see A. Testa and G. Armstrong, "We are
} Against Islam! The Lega Nord and the Islamic Folk Devil", SAGE Open, 2(4) 2012, doi: $10.1177 / 2158244012467023,15$ pages.

${ }^{6}$ N. C. Funk and A. A. Said, "Islam and the West: Narratives of Conflict and Conflict Transformation", International Journal of Peace Studies, 9(1) (2004, p. 9).

${ }^{7}$ For an analysis of such stereotypes in American popular culture, see J. G. Shaheen, Arab and Muslim stereotyping in American popular culture. Occasional Paper, Center for Muslim-Christian Understanding, History and International Affairs, Edmund A. Walsh School of Foreign Service (Washington, DC: Georgetown University, 1997.

${ }^{8}$ Pew Research Center, Mapping the Global Muslim Population: A Report on the Size and Distribution of the World's Muslim Population, October 2009, Washington, DC: Pew Forum, 2009, Available at: http://www.pewforum.org/2009/10/07/mapping-the-global-muslim-population/ [Accessed October 23, 2013].

${ }^{9}$ T. Modood, "Remaking Multiculturalism After 7/7", Open Democracy, September 29, 2005, Available at: www.openDemocracy.net [Accessed November 1, 2013].

${ }^{10}$ S. Khan and M. Ahmad, "A Muslim Perspective on Racial Discrimination Act Amendments", The Conversation, 23 April 2014, Available at: http://theconversation.com/a-muslim-perspective-on-racialdiscrimination-act-amendments-25596 [Accessed 01/07/2014].

${ }^{11}$ Saeed and Drainville 2006, quoted in A. Saeed, "Media, Racisms and Islamophobia: The Representation of Islam and Muslims in the Media", Sociology Compass, 1(2) (2007, p. 453).

${ }^{12}$ E. W. Said, Covering Islam: How the Media and the Experts Determine How We See the Rest of the World (New York: Random House, 2008, p. xxii).

${ }^{13}$ R. Jackson, "Constructing Enemies: 'Islamic Terrorism' in Political and Academic Discourse", Government and Opposition, 42(3) (2007, p.400).

${ }^{14}$ Pankaj Mishra, "A Paranoid, Abhorrent Obsession”, The Guardian, December 8, 2007.

${ }^{15}$ E. W. Said, Covering Islam: How the Media and the Experts Determine How We See the Rest of the World, op. cit.

${ }^{16}$ When their Prophet's name is mentioned, Muslims use the phrase 'peace be upon him' to show their respect. They are also encouraged to use similar salutation when other prophets' names are mentioned.

${ }^{17}$ P. Weller, A. Feldman, and K. Purdam (with contributions from A. Andrews, A. Doswell, J. Hinnells, M. Parker-Jenkins, S. Parmar and M. Wolfe of the University of Derby), Religious Discrimination in England and Wales, Home Office Research Study 220, London: Home Office Research, Development and Statistics Directorate, February 2001, Available at: http://www.religionlaw.co.uk/reportad.pdf [Accessed November 2, 2013].

${ }^{18}$ United Nations Development Programme (UNDP), Human Development Report 2004. Cultural Liberty in Today's Diverse World (New York: UN, 2004, p. 2).

${ }^{19}$ N. Hopkins, "Dual Identities and Their Recognition: Minority Group Members' Perspectives", Political Psychology, 32(2) (2011, p. 259).

${ }^{20}$ T. Modood and R. Kastoryano, "Secularism and the Accommodation of Muslims in Europe" in T. Modood, A. Triandafyllidou, and R Zpata-Barrero (eds.), Multiculturalism, Muslims and Citizenship: A European Approach (162-178) (London/Oxon: Routledge, 2006).

${ }^{21}$ Pew Research Center, Support of Terror Wanes Among Muslim Publics. Islamic Extremism: Common Concern for Muslim and Western Publics, 17-Nation Pew Global Attitudes Survey, Washington, DC: The Pew Global Project Attitudes, July 2005, Available at: http://www.pewglobal.org/files/pdf/248.pdf [Accessed November 3, 2013]. 
${ }^{22}$ C. Taylor, "The Politics of Recognition”, in A. Heble, D. Palmateer Pennee, and J R (Tim) Struthers (eds.), New Contexts of Canadian Criticism (98-99) (Ontario: Broadview Press, 1997).

${ }^{23}$ Collins English Dictionary, Definition of "Islamic Fundamentalism”, Online, Available at: http://www.collinsdictionary.com/dictionary/english/islamic-fundamentalism [Accessed November 12, 2013].

I $38 \quad{ }^{24}$ Sunnah includes the specific words, habits, practices, and silent approvals of Prophet Muhammad. Muslims refer to Sunnah for guidance and direction on issues of daily lives which are not directly addressed in the Qur'an.

${ }^{25}$ Cultural Muslims, also referred to as 'nominal' Muslims are religiously unobservant, secular, or even irreligious individuals who still identify themselves as Muslims due to being born and brought up in a Muslim family or having been influenced by the social and cultural environment in which they grew up. For more explanation, see A. Saeed and H. Saeed, Freedom of Religion, Apostasy, and Islam (Farnham, Surrey: Ashgate Publishing Limited, 2004, p.171).

${ }^{26}$ The Qur'an is the Muslim holy book containing God's message revealed in Arabic to Prophet Muhammad over 1400 years ago in Makkah (Mecca), Saudi Arabia, by Archangel Jibril (Gabriel).

${ }^{27}$ See Qur'an Chapter 2 Verse 256 and Chapter 109, Verse 6. For a deeper understanding of how Prophet Muhammad practiced and encouraged others to practice these values, see T. Ramadan, In the Footsteps of the Prophet: Lessons from the Life of Muhammad (Oxford: Oxford University Press, 2007).

${ }^{28}$ For details, see B. Parekh,'Europe, Liberalism and the 'Muslim Question' “in T. Modood, A.

Triandafyllidou, and R. Zpata-Barrero (eds.), Multiculturalism, Muslims and Citizenship: A European Approach (179-203) (London/Oxon: Routledge, 2006).

${ }^{29}$ S. Glynn, "Liberalizing Islam: Creating Brits of the Islamic Persuasion”, in R. Phillips (ed.), Muslim Spaces of Hope: Geographies of Possibility in Britain and the West (London/New York: Zed Books,, 2009, p. 180).

${ }^{30}$ P. Jones, "Bearing the Consequences of Belief", The Journal of Political Philosophy, 2(1) (1994), pp. 2443.

${ }^{31}$ The headscarf worn by many Muslim women is referred to as 'hijab'. However, hijab means more than just a head scarf; in Arabic, the word 'hijab' means veil, curtain, or cover. Muslim women are required to wear the hijab, i.e. the two pieces of garment, the jilbaab (outer cloak, a long garment that is ample enough to cover the entire body) and the khimaar (headscarf).

${ }^{32}$ Controversial Irish-Australian bushranger Ned Kelly is dubbed by Geoffrey Robertson, QC, as 'Jihad Ned' explaining that since Kelly was engaged in terrorist atrocity against the police and the blacks, he was a terrorist and, therefore, "was on a jihad against the police, against the blacks". Watch G. Robertson, In Conversation With ABCs Leigh Sales, ABC Television (Australia), Available at: http://www.abc.net.au/tv/bigideas/browse/video [Viewed September 16, 2013].

${ }^{33}$ R. Jackson, “Constructing Enemies: 'Islamic Terrorism' in Political and Academic Discourse”, op.cit. p. 401.

${ }^{34}$ B. Handwerk, What Does "Jihad" Really Mean to Muslims?, National Geographic News, Available at: http://news.nationalgeographic.com.au/news/2003/10/1023_031023_jihad.html [Accessed October 28, 2010].

${ }^{35}$ M. Hathout, Jihad vs. Terrorism (Nevada: Dawn Publications, 2002, p. 18).

${ }^{36}$ T. Ramadan, In the Footsteps of the Prophet: Lessons from the Life of Muhammad, op.cit. p. 99.

${ }^{37}$ S. Glynn, Liberalizing Islam: Creating Brits of the Islamic Persuasion, op. cit.

${ }^{38}$ For an elaboration on this, see S. Khan, “'Islamic Fundamentalism' in the Asia-Pacific Region: Failures of Civil Societies or Backlash against the US Hegemony?” In P. Jain, F. Patrikeeff and G. Groot (eds.), Asia-Pacific and a New International Order: Responses and Options (New York: Nova Science Publishers, pp. 71-88)

${ }^{39}$ Yuval-Davis (1993:628) quoted in S. McPhee, Muslim Identity: The European Context, Sussex Migration Working Paper No. 34, (Brighton: Sussex Centre for Migration Research, University of Sussex, 2005), Available at: https://www.sussex.ac.uk/webteam/gateway/file.php?name=mwp34.pdf\&site=252 [Accessed November 7, 2013].

${ }^{40}$ B. Parekh, "Political Theory and the Multicultural Society", Radical Philosophy, RP 095, May/June 1999, Available at: http://red.pucp.edu.pe/wp-content/uploads/biblioteca/081232.pdf [Accessed November 12, 2013].

${ }^{41}$ See Office of the High Commissioner for Human Rights, International Covenant on Civil and Political Rights, Adopted and Opened for Signature, Ratification and Accession by General Assembly resolution 2200A (XXI) of 16 December 1966, Entry into Force 23 March 1976, in accordance with Article 49, Geneva: OHCHR.

${ }^{42}$ European Council on Refugees and Exiles, Position on the Integration of Refugees in Europe (Brussels: ECRE Brussels Office/Secretariat, 2002). 
${ }^{43}$ T. Modood, "Muslims and the Politics of Difference", The Political Quarterly, 74(1) ( Supplement s1) (2003), p. 106.

${ }^{44}$ For an exposition of such views, see, for example, B. Lewis, "Islam and Liberal Democracy", The Atlantic Monthly, 271(2) (1993), pp. 89-98, and F. Fukuyama, "Identity and Migration" Prospect Magazine, 131(25) (2007), Available at: https://www.prospectmagazine.co.uk/magazine/identity-migrationmulticulturalism-francis-fukuyama/ [Accessed November 11, 2013].

${ }^{45}$ United Nations Development Programme, "Human Development Report 2004. Cultural Liberty in

Today's Diverse World", op.cit. p. 4.

46 ibid, p. 1

47 ibid, p. 6

${ }^{48}$ W. Aly, "Multiculturalism, Assimilation and the Politics of Terrorism ", Papers on Parliament No. 56, 2011, Canberra: Parliament of Australia, Available at:

http://www.aph.gov.au/About_Parliament/Senate/Research_and_Education/pops/pop56/c05 [Accessed October 11, 2013].

${ }^{49}$ See Z. Nyiri, Muslims in Berlin, London, and Paris: Bridges and Gaps in Public Opinion, Gallup World

Poll- ThinkForum: Muslims in Europe, Princeton, NJ: The Gallup Organization, 2007), Available at:

//media.gallup.com/WorldPoll/PDF/WPTFMuslimsinEuropeExecSumm.pdf [Accessed November 10,

2013].

${ }^{50}$ ibid, p.2

${ }^{51}$ B. Parekh,"Europe, Liberalism and the 'Muslim Question'“, op.cit.

${ }^{52}$ The Oxford Dictionary defines a folk devil as "a person or thing held to be a bad influence on society".

${ }^{53}$ R. M. Eckersley, "Culture, Spirituality, Religion and Health: Looking at the Big Picture", The Medical Journal of Australia, 186(10) (2007), p. S 55.

${ }^{54}$ Contrast the perception of the West about Buddhists and Muslims. Notwithstanding the Buddhist monks under fire in Thailand for inappropriate behaviour or those who have been repeatedly accused of attacking or inciting violence against Muslim Rohingyas in Myanmar, neither has Buddhism been placed under scrutiny nor have Buddhists in other parts of the world been condemned for acts which they have not committed.

${ }^{55}$ Y. Y. Haddad and T. Golson, "Overhauling Islam: Representation, Construction, and Co-option of "Moderate Islam" in Western Europe", Journal of Church and State, 49(3) (2007), p.488.

${ }^{56}$ S. Glynn, "Liberalizing Islam: Creating Brits of the Islamic Persuasion", op. cit., p. 192.

${ }^{57}$ T. Asad, "Free Speech, Blasphemy, and Secular Criticism" in Is Critique Secular? Blasphemy, Injury, and Free Speech, Townsend Papers in the Humanities Series (Berkeley: Townsend Centre for the Humanities, University of California, 2009), p. 46.

58 ibid, p. 56

${ }^{59}$ P. Morey and A. Yaqin, Framing Muslims: Stereotyping and Representation After 9/11 (Cambridge, MA: Harvard University Press, 2011), p. 215.

${ }^{60}$ E. W. Said, Covering Islam: How the Media and the Experts Determine How We See the Rest of the World, op.cit. pp. 10-11.

${ }^{61}$ Published in 1988, The Satanic Verses is a highly controversial novel by Salman Rushdie that, according to many Muslims, contains blasphemous references to Prophet Muhammad.

${ }^{62}$ See Jyllands-Posten, September 30, 2005. 12 caricatures of Prophet Muhammad drawn by commissioned satirists were published.

${ }^{63}$ For more, see J. Foster, "Prophets, Cartoons, and Legal Norms; Rethinking the United Nations

Defamation of Religion Provisions," Journal of Catholic Legal Studies, 48(1) (2009), pp. 19-57.

${ }^{64}$ P. Jones, "Religious Belief and Freedom of Expression: Is Offensiveness Really the Issue?", Res

Publica, 17(.1) (2011), pp. 77-78.

${ }^{65}$ J. Dempsey and M. Landler, "Opera Cancelled Over a Depiction of Muhammad", The New York Times, September 27, 2006.

${ }^{66}$ See S. Khan and M. Ahmad, "A Muslim Perspective on Racial Discrimination Act Amendments", op.cit.

${ }^{67}$ Telecasted on ABC2 (Australian Broadcasting Corporation), October 05, 2013.

${ }^{68}$ S. Ellis, "Ricky Gervais raises bar again with daring comedy", The Sydney Morning Herald, August 16, 2013.

${ }^{69}$ Pastor Terry Jones of the Dove World Outreach Center in Florida and author of the book Islam is of the Devil, planned to host "Burn a Quran Day" in 2010 to mark the ninth anniversary of the 9/11 attacks. For more, view L. Russell, "Church Plans Quran-burning Event", CNN, July 31, 2010,

http://edition.cnn.com/2010/US/07/29/florida.burn.quran.day/index.html

${ }^{70}$ D. Nowak, "Russian Curators Sentenced But Not Imprisoned", The Guardian, July 13, 2010, Available at: http://www.theguardian.com/world/feedarticle/9169345 [Accessed October 12, 2013] 


\section{Shamsul Khan, Mahjabeen Ahmad}

${ }^{71}$ The Blessed Virgin Chastises the Infant Jesus before Three Witnesses (1926), Max Ernst's painting exhibited at the Metropolitan Museum of Art., New York, in April-July, 2005.

${ }^{72}$ P. Jones, "Bearing the Consequences of Belief", op.cit. p. 34.

73 ibid, p. 37

${ }^{74}$ P. Jones, "Religious Belief and Freedom of Expression: Is Offensiveness Really the Issue?" op.cit. p. 76.

${ }^{75}$ T. Modood, "Muslims and the Politics of Difference", op.cit. pp. 100-115.

${ }^{76}$ ibid. p. 101

${ }^{77}$ R. Jackson, Constructing Enemies: 'Islamic Terrorism' in Political and Academic Discourse, op.cit. p. 418.

${ }^{78}$ Rohingyas are a Muslim minority population who live mainly in the state of Arakan in Myanmar

(Burma) but are denied citizenship and legal rights by the Myanmar government. Because of their race and religion, they have been enduring unspeakable torture but their plight remains largely forgotten. Even Myanmar's Opposition leader and Nobel Peace Prize winner Aung San Suu Kyi, regarded as an icon of democracy by the West, has put political exigency ahead of her moral responsibility in this regard but has not been criticised by the protagonists of human rights in the West.

${ }^{79}$ For details, see P. Morey and A. Yaqin, Framing Muslims: Stereotyping and Representation After 9/11, op.cit.

${ }^{80}$ Pew Research Center, The World's Muslims: Religion, Politics, and Society (Washington, DC: The Pew Forum on Religion and Public Life, 2013), p. 62.

${ }^{81}$ An Arabic word meaning 'nation' or 'community'; the concept of ummah is based on the belief in the brotherhood of Muslims, the acceptance that all Muslims irrespective of language and nationality are members of one transnational community, almost like an extended family, and as such, must be concerned with collective welfare. Thus, Muslims are bonded by belief irrespective of race, culture, language, nationality, or other markers of difference.

${ }^{82}$ Y. Islam, "They Have Hijacked My Religion", The Independent, October 26, 2011.

${ }^{83}$ M. Hussain, "The Special Dread of Terrorism for Muslims in the West", The Guardian, April 23, 2013.

${ }^{84}$ For a detailed exposition on state of democracy in Muslim countries, see A. Karatnycky, "Muslim

Countries and the Democracy gap." Journal of Democracy, 13(1) (2002): 99-112.

${ }^{85}$ Pew Research Center, Religion in the News: Islam and Politics Dominate Religion Coverage in 2011

(Washington DC: Religion and Public Life Project), February 23, 2012, Available at:

http://www.pewforum.org/2012/02/23/religion-in-the-news-islam-and-politics-dominate-religion-coveragein-2011/ [Accessed June 20, 2014].

${ }^{86}$ Pew Research Center, After Boston, Little Change in Views of Islam and Violence (Washington DC: Pew Research Project on Muslim-Western Relations), May 7, 2013, Available at

http://www.pewresearch.org/topics/muslim-western-relations/ [Accessed July, 20, 2013].

${ }^{87}$ Y. Al-Qaradawi, Islamic Awakening: Between Rejection and Extremism (London/Washington, DC: The International Institute of Islamic Thought, 2006), pp.72-77.

${ }^{88}$ F. Halliday, “'Islamophobia' Reconsidered”, Ethnic and Racial Studies, 22(5) (1999), p. 896.

${ }^{89}$ The militant group the Islamic State of Iraq and Syria (ISIS), also known as Islamic State of Iraq and the Levant (ISIL)

${ }^{90}$ Halliday, op.cit..

${ }^{91}$ ibid, p. 897.

${ }^{92}$ S. McPhee, Muslim Identity: The European context, op.cit.

${ }^{93}$ Amin Maalouf, has provided a very interesting analysis of the innate human need for belonging to a community in the first section of his book Les Identités meurtrières under the heading "Mon identité, mes appurtenances". For details, see A. Maalouf, Les Identités meurtrières (Paris: Grasset, 1998).

${ }^{94}$ N. C. Funk and A. A. Said, "Islam and the West: Narratives of Conflict and Conflict Transformation", op.cit. p. 11.

${ }^{95}$ Ohio Northern University, Dr. Martin Luther King Jr.'s Presentation, Accessed November 3, 2013, http://www.onu.edu/node/28509

${ }^{96}$ M. Cinalli and M. Giugni, "Political Opportunities, Citizenship Models and Political Claim-making over Islam", Ethnicities, 13(2) (2013), p. 151.

${ }^{97}$ T. Choudhury, The Role of Muslim Identity Politics in Radicalisation (A Study in Progress) (London: Department for Communities and Local Government), p. 6.

${ }^{98}$ Ohio Northern University, Dr. Martin Luther King Jr.'s Presentation, op.cit. 